\title{
Two new species of the genus Metapocyrtus Heller, 1912 (Coleoptera, Curculionidae, Entiminae, Pachyrhynchini), subgenus Orthocyrtus Heller, 1912, from Mindanao Island, Philippines
}

\author{
Analyn A. Cabras', Milton Norman Medina', Maurizio Bollino² \\ I Coleoptera Research Center, Institute of Biodiversity and Environment, University of Mindanao, Davao City, \\ 8000, Philippines 2 Museo di Storia naturale del Salento, 73021 Calimera, Lecce, Italy \\ Corresponding author: Analyn A. Cabras (ann.cabras24@umindanao.edu.ph)
}

Academic editor: M. Alonso-Zarazaga | Received 12 January 2021 | Accepted 10 March 2021 | Published 8 April 2021

http://zoobank.org/4E4AFOB3-B87C-4715-B74E-30C3B48D4C4D

Citation: Cabras AA, Medina MN, Bollino M (2021) Two new species of the genus Metapocyrtus Heller, 1912 (Coleoptera, Curculionidae, Entiminae, Pachyrhynchini), subgenus Orthocyrtus Heller, 1912, from Mindanao Island, Philippines. ZooKeys 1029: 139-154. https://doi.org/10.3897/zookeys.1029.63023

\begin{abstract}
Two new species of Metapocyrtus Heller, 1912, subgenus Orthocyrtus Heller, 1912 (Coleoptera, Curculionidae, Entiminae, Pachyrhynchini) are described and illustrated from Mindanao Island, Philippines. The species are Metapocyrtus (Orthocyrtus) davaoensis sp. nov. and Metapocyrtus (Orthocyrtus) hirakui sp. nov. from Davao City and Bukidnon, respectively. Brief bionomical notes and phenotypic characters compared to their sympatric Entiminae counterparts are also reported. The discovery of $M$. (O.) davaoensis sp. nov. in Davao City confirms how understudied Coleoptera are in Mindanao and underlines the potential for the discovery of new species even in highly urbanized areas.
\end{abstract}

\section{Keywords}

Bionomic, new taxa, taxonomy, urban biodiversity, weevils

\section{Introduction}

The tribe Pachyrhynchini has achieved notoriety for its beautiful iridescent markings making its species conspicuous and one of the most well-known beetle taxa in the Philippines. It currently counts 18 genera with roughly 500+ described species. Being wingless,

Copyright Analyn A. Cabras et al. This is an open access article distributed under the terms of the Creative Commons Attribution License (CC BY 4.0), which permits unrestricted use, distribution, and reproduction in any medium, provided the original author and source are credited. 
most Pachyrhynchini have a very narrow geographic range and are mostly endemic to an island or a mountain range. According to the Forest Management Bureau of the Department of Environment and Natural Resources, forest cover in the Philippines has dropped by $70 \%$, from 21 million hectares in 1900 to approximately 6.5 million hectares in 2007 . This loss of forests has consequently caused the majority of the species from this tribe to be listed as Vulnerable in the latest national assessment of the Department of Environment and Natural Resources (DENR Administrative Order 2019). The genus Metapocyrtus Heller, 1912 is endemic in the Philippines and is the most speciose and complex within the tribe (Schultze 1923; Cabras et al. 2018; Bollino et al. 2020). Metapocyrtus subgenus Orthocyrtus Heller, 1912 currently counts more than 36 species distributed all over the Philippines: 18 species were described from Luzon, four species and one subspecies from Visayas, 12 species from Mindanao Island, and three were generically described from the Philippines (Schultze 1925; Cabras et al. 2018; Cabras and Medina 2019).

Mindanao Island is the second largest island in the Philippines with a total area of $97,530 \mathrm{~km}^{2}$ divided into six political regions and five faunal biogeographic subregions. The unique biogeographic history of Mindanao Island was formed as a by-product of paleo-island accretion in identified suture zones (Yumul 2003), and its recent connectivity to several shallow-water neighboring islands during the last Pleistocene sealevel fluctuations (e.g., Samar, Leyte, Bohol, Dinagat, and Siargao). Such inter-island connectivity led to the formation of the identified Greater Mindanao Pleistocene Aggregate Island Complex which allowed for faunal exchange and gene flow among species (Rohling et al. 1998; Brown and Diesmos 2001). Despite the recent efforts to document the island's coleopterological fauna, many species remained unclassified including two new taxa recently collected in Davao City and Bukidnon. Upon examination, the new species have been found to belong to the subgenus Orthocyrtus based on characters indicated by Cabras et al. (2018). Both species and their habitats are described and illustrated here; we also include some comments on sympatric beetles which apparently belong to the same mimetic ring.

\section{Materials and methods}

The specimens deposited in the University of Mindanao Coleoptera Research Center were collected through sheet beating and hand picking and killed in vials with ethyl acetate. Morphological characters were observed under Luxeo 4D and Nikon SMZ745T stereomicroscopes. The illustrations, as well as the treatment of the genitals, were identical to those described by Bollino and Sandel (2017), including that of endophallus eversion by using the Berti-Vachon method (Bontems 2013). Images of the habitus and genitalia were taken using a Nikon D5300 digital camera with a Sigma 18-250 macro lens, while the image of the endophallus was taken with a Nikon D90 digital camera, and Laowa $25 \mathrm{~mm} \mathrm{f/2.8}$ 2.5-5X Ultra Macro lens. All images were stacked and processed using a licensed version of Helicon Focus 6.7.0 and Photoshop CS6 Portable software. Label data are indicated verbatim. Measurements mentioned in this paper are abbreviated as follows: 
/ different lines

// different labels

â arithmetic mean rounded to one decimal place;

LB body length, from the apical margin of pronotum to the apex of elytra;

LE elytral length, from the level of the basal margins to the apex of elytra;

LP pronotal length, from the base to apex along the midline;

LR length of rostrum;

WR maximum width across the rostrum;

WE maximum width across the elytra;

WP maximum width across the pronotum.

Comparative materials and specimens used in the study are deposited in the following institutional collections:

DUBC Daugavpils University Beetle Collection, Daugavpils, Latvia;

MBLI private collection of Maurizio Bollino, Lecce, Italy;

NIAES National Institute for Agro-Environmental Sciences, Tsukuba, Japan;

SMTD Senckenberg Natural History Collections, Dresden, Germany;

UMCRC University of Mindanao Coleoptera Research Center, Davao City Philippines; ZMPC private collection of Zhao Ming, Guangzhou, China.

\section{Results}

Metapocyrtus (Orthocyrtus) davaoensis sp. nov. http://zoobank.org/DC3785AE-085A-4E26-8AA8-460601F0DA9D

Figs $1-4$

Holotype (Figs 1, 3), male: Philippines - Mindanao / Calinan / Davao City / March.2018 / coll. Medina (typed on white card) // HOLOTYPE male / Metapocyrtus (Orthocyrtus) davaoensis / CABRAS, MEDINA \& BOLLINO, 2021 (typed on red card). Presently in UMCRC, will be deposited in National Museum of Natural History (PNMNH) under the National Museum of the Philippines.

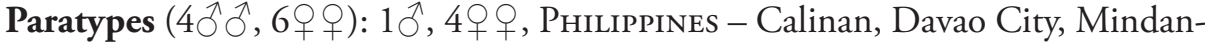
ao Island / March 2018/ coll. Cabras, all in UMCRC; 10 , 1 \% , PhiLippines - Gumitan, Davao del Sur, Mindanao Island/ XI, 2019/ Leg-local collector/, in coll. ZMPC; 10̂, Philippines - Mindanao I. / Tabayon - Davao del Sur / March 2014 / Lg. local people - coll. Bollino; 10̄, PHILIPPINES - Mindanao / Kapatagan / (Davao del Sur) / January 2016 / Lg. local people - coll. Bollino; 19, Philippines - Mindanao / Cabanglasan - Bukidnon / XII.2014-I.2015 / ex Lumawig - coll. Bollino, all in MBLI. All paratypes with additional red label: PARATYPE / Metapocyrtus (Orthocyrtus) davaoensis / CABRAS, MEDINA, \& BOLLINO, 2021. 

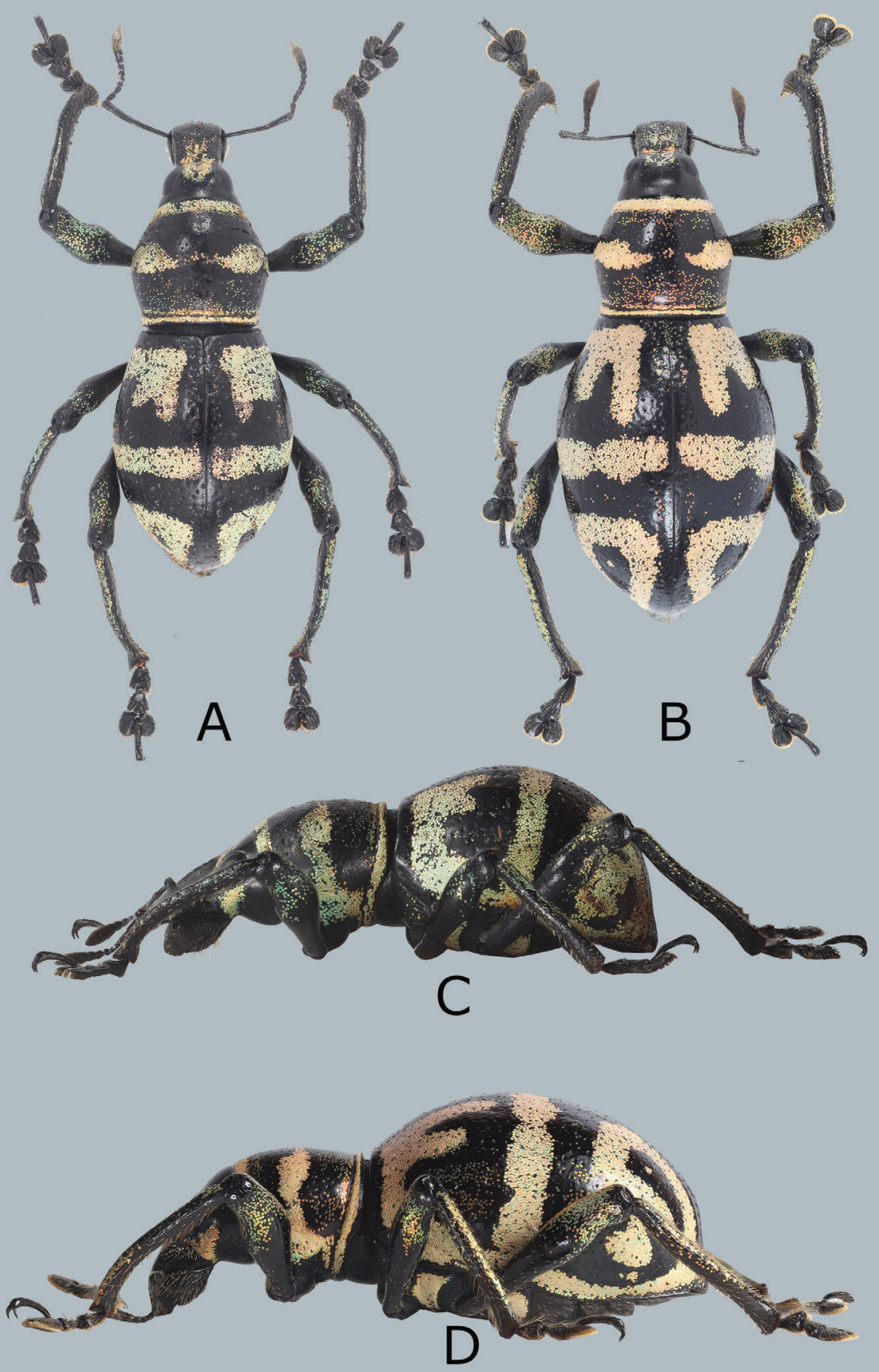

Figure I. Metapocyrtus (Orthocyrtus) davaoensis sp. nov. A male holotype, dorsal view B female, dorsal view $\mathbf{C}$ ditto,male, lateral view $\mathbf{D}$ ditto,female, lateral view. 


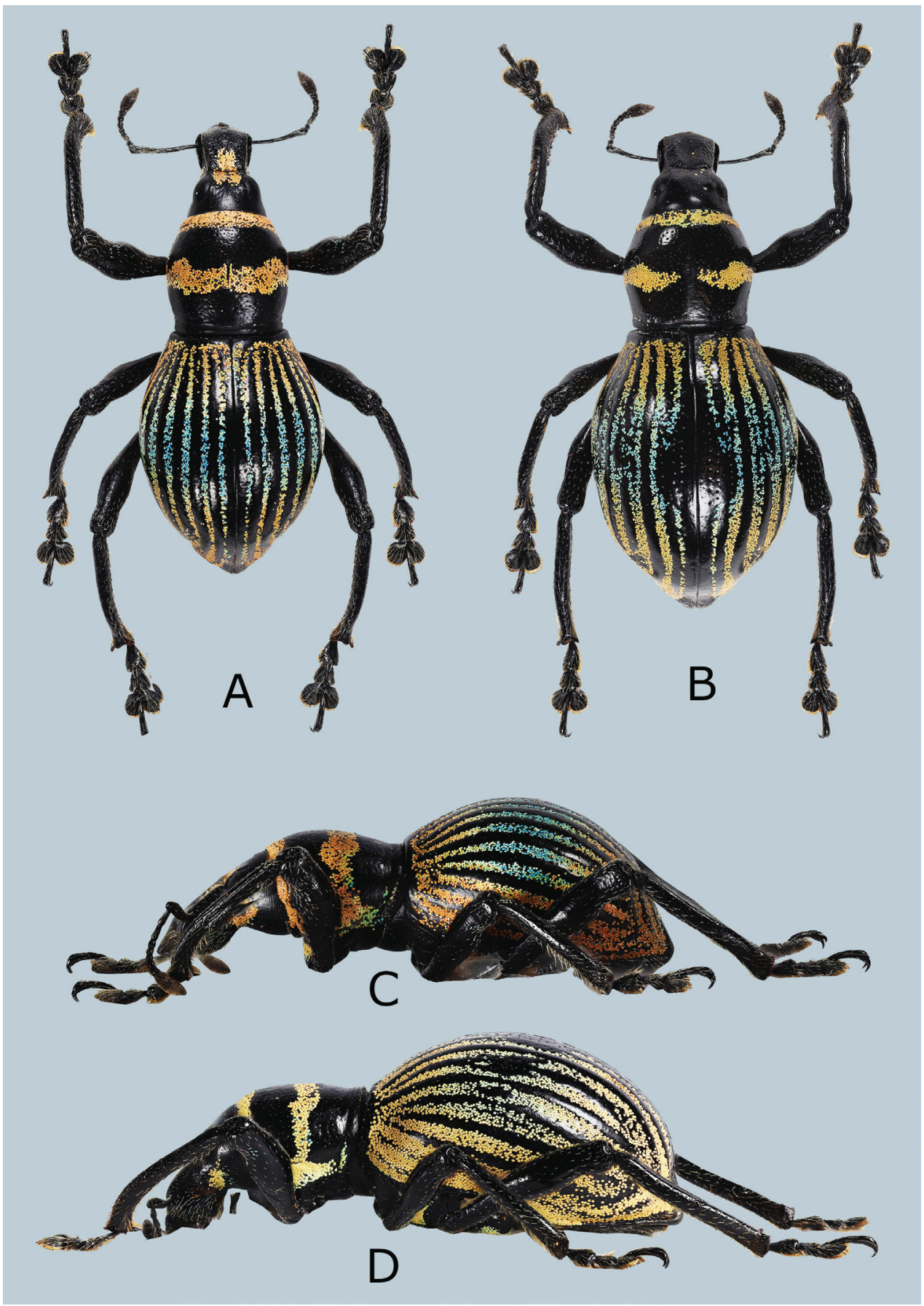

Figure 2. Metapocyrtus (Orthocyrtus) hirakui sp. nov. A male holotype, dorsal view B female, dorsal view $\mathbf{C}$ ditto, male, lateral view $\mathbf{D}$ ditto, female, lateral view. 
Diagnosis. Metapocyrtus (Orthocyrtus) davaoensis sp. nov. in general appearance resembles Metapocyrtus (Orthocyrtus) mansaka Cabras, Bollino \& Medina, 2018 from Davao de Oro, South Cotabato, and Agusan del Sur, but differs for its unique elytral ornamentation, pronotal markings and shape of the aedeagus. Metapocyrtus (O.) davaoensis elytral ornamentation consist of short stripes from behind the base to before the middle of stria II and behind the base to the basal third of interval IV, a thin median transverse band starting from interval I towards the lateral margin, a distorted subtriangular stripe on apical third extending from stria I to interval IV, and a long stripe from behind the base to the apex along the lateral margin, confluent with the basal, medial and apical stripes. Metapocyrtus (O.) mansaka has three broad, scaly bands on the elytra; for pronotal marks, $M$. (O.) davaoensis has thin, transverse, scaly marks along the entire width in the middle compared with $M$. (O.) mansaka which has triangular transverse scaly marks from each side dilated towards the middle but not confluent.

Description. Male. Dimensions (in mm): LB 10.0-10.3 (holotype 10.0, â: 10.15), LR 1.8-1.9 m (1.8, â: 1.85), WR 1.5-1.6 (1.5 mm, â: 1.55), LP 3.0-3.3 (3.0, â: 3.15), WP: 3.3-3.4 (3.3, â: 3.35), LE 6.4-6.6 (6.4, â: 6.5). WE 4.7-4.9 (4.7 mm, â: 4.8). $N=3$. Integument black. Body surface, rostrum, head, and underside with a weak luster.

Body subglabrous. Head glabrous, sparsely minutely pubescent on ventral side, with metallic, pale-yellow ochre, elliptical scales on each side and turquoise, hair-like scales on lateroventral parts; forehead between eyes covered with metallic, light-yellow ochre, round scales. Rostrum strongly rugose, longer than wide (LR/WR: 1.2), bearing minute, yellow-ochre, adpressed hairs on the lateral surface, and lateroventral sides below antennal scrobe covered with long, light-colored hairs; transverse basal groove distinct; longitudinal groove along midline distinct, creating a shallow depression beset with metallic, golden-yellow, round scales; lateral sides with round to elliptical light-yellow ochre scales; dorsum finely punctured; dorsal surface weakly convex. Eyes medium-sized and feebly convex. Antennal scape and funicle of almost the same length, moderately covered with fine, light-colored hairs. Funicular segments I and II almost of the same length, twice as long as wide; segments III-VII nearly as long as wide; club subellipsoidal, nearly three times longer than wide. Prothorax subglobular, slightly wider than long (LP/WP: 0.91), finely punctured, widest at middle, weakly convex, sparsely covered with turquoise and light-yellow ochre, round scales on basal half of dorsum, and with the following scaly markings of metallic, lightyellow ochre and turquoise, round scales: a) thin band at the anterior margin, b) transverse band in the entire width in middle, c) thin band at the posterior margin, and d) broad lateroventral stripe before the coxa confluent with the anterior and posterior marginal bands. Elytra subovate (LE/WE:1.36), slightly wider and moderately longer than prothorax (WE/WP: 1.42, LE/LP: 2.13), body surface black with sparse, golden-yellow and turquoise, round scales, subglabrous, finely punctured, moderately convex; apex with sparse, white, fine hairs. Each elytron with the following scaly markings of metallic, light-yellow ochre to turquoise, round scales: a) short stripe from behind base to before middle of stria II, b) short stripe from behind base to basal third of interval IV, basally confluent with stripe on stria II, c) thin, median, transverse band starting from interval I towards lateral margin, d) distorted subtriangular 


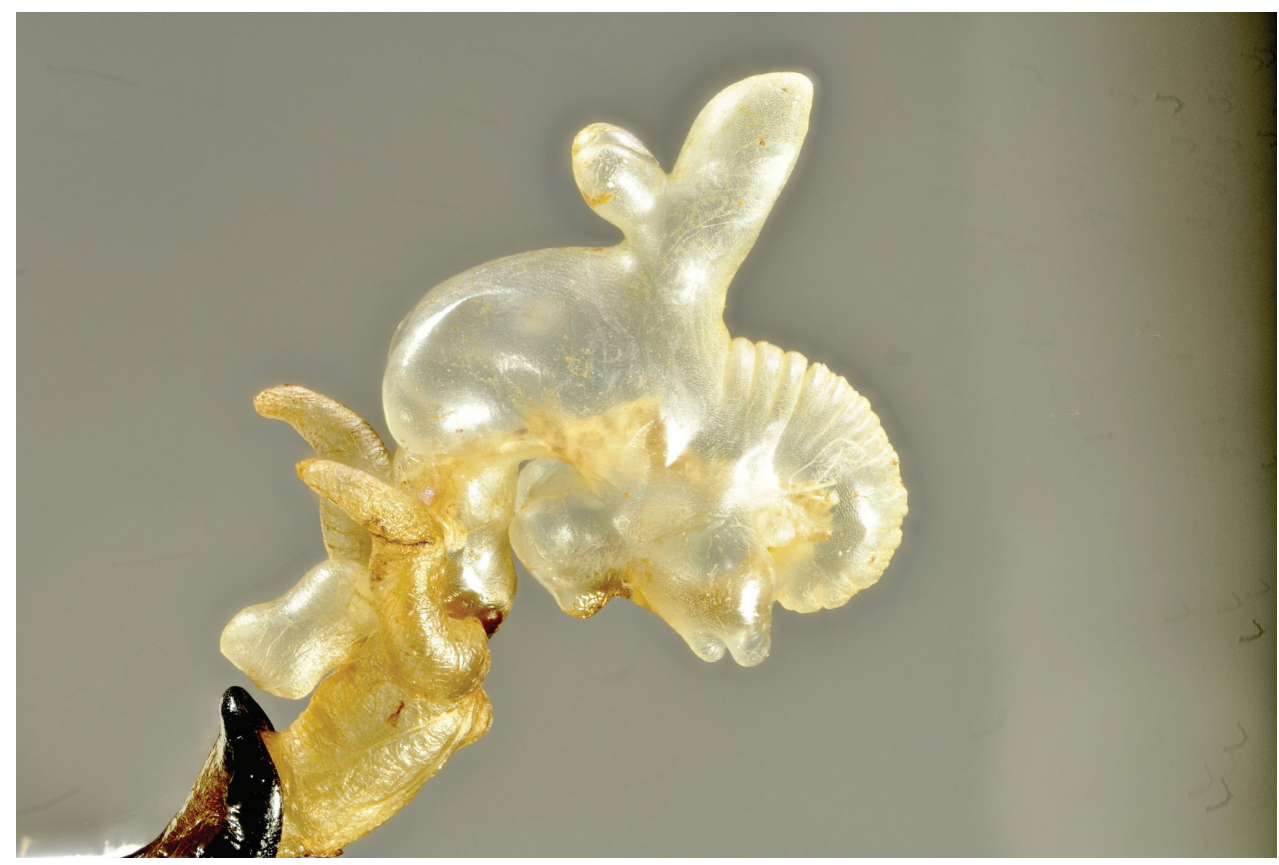

Figure 3. Metapocyrtus (Orthocyrtus) hirakui sp. nov. everted endophallus, lateral view.

stripe on apical third extending from stria I to interval IV, e) small dot on interval V at apical quarter, at times confluent with the distorted subtriangular stripe, f) long stripe from behind base to apex along lateral margin, confluent with basal, median, and apical stripes. Legs with strong clavate femora. Femora sparsely covered with light-colored hairs, with apical half covered with turquoise, elliptical scales. Tibiae covered with subrecumbent, light-colored bristles and metallic-turquoise and golden-yellow elliptical scales towards apical part, weakly serrate along inner edge. Fore tibiae bear a mucro at apex. Tarsomeres covered with sparse pubescence. Coxae barely pubescent with very sparse, turquoise, hair-like scales. Mesosternum covered with light-colored, adpressed bristles. Metasternum with light-colored, adpressed bristles and sparse, light-yellow ochre, round scales at lateral sides. Ventrite 1 depressed on disc, with light-yellow ochre and turquoise, round scales towards lateral margin. Ventrites 2-5 sparsely covered with adpressed bristles, especially towards margin. Ventrite $\mathrm{V}$ flattened, apical half finely densely punctured, interspersed sparsely with bluish, hair-like scales. Ventrites 1-5 with dense and long, light-brown bristles, laterally with sparse light-green bristles.

Male genitalia as shown in Figure 2A-C.

Due to of the few males available (only three, excluding the holotype), we were unable to obtain even a partial evertion of the endophallus (read below for more comments).

Female. Dimensions (in mm): LB 12.0-12.7 (â: 12.33), LR 2.0.-2.1 (â: 2.05), WR 1.7-1.8 (â: 1.75). LP 3.0-3.2 (â: 3.08). WP 4.2-4.5 (â: 4.33), LE 9.0-9.5 (â: 9.23). WE 6.9-7.5 (â: 7.18). $N=4$.

Habitus as shown in Figure 1D-F. 


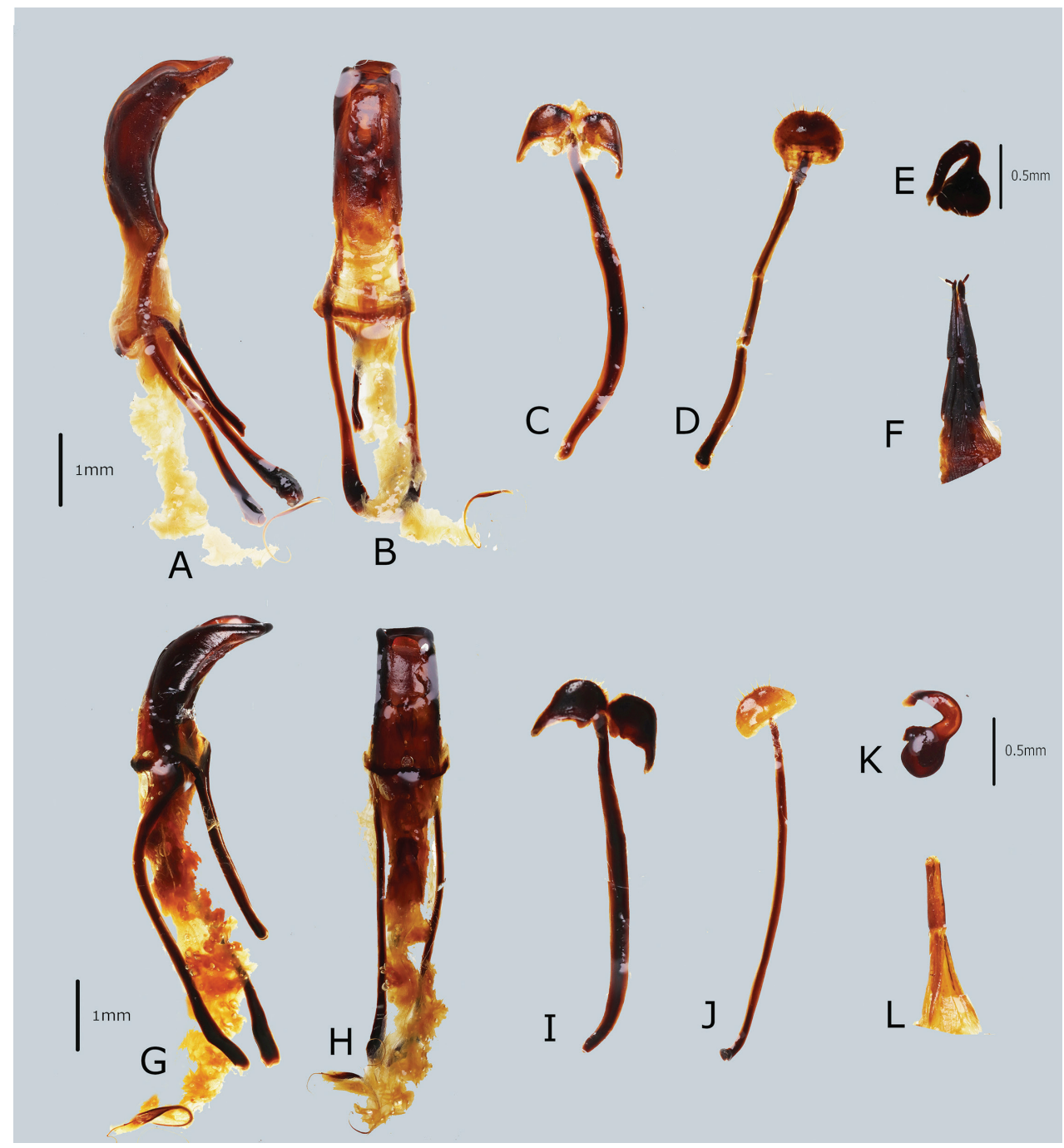

Figure 4. Male genitalia and female terminalia of Orthocyrtus spp. A-F Metapocyrtus (Orthocyrtus) davaoensis sp. nov. A penis in lateral view $\mathbf{B}$ idem. in dorsal view $\mathbf{C}$ sternite IX in dorsal view $\mathbf{D}$ sternite VIII in ventral view $\mathbf{E}$ spermatheca $\mathbf{F}$ ovipositor in dorsal view G-L Metapocyrtus (Orthocyrtus) hirakui sp. nov. $\mathbf{G}$ penis in lateral view $\mathbf{H}$ idem. in dorsal view $\mathbf{I}$ sternite IX in dorsal view $\mathbf{J}$ sternite VIII in ventral view $\mathbf{K}$ spermatheca $\mathbf{L}$ ovipositor in dorsal view.

Females differ from males in the following: a) pronotum wider than long (LP/WP 0.71 ), slightly shorter than in male; b) pronotum imperfectly subglobular, and c) elytra imperfectly subovate (LE/WE 1.27-1.3), longer and wider (WE/WP 1.64-1.67, LE/ LP 2.97-3.0) than in male, widest before middle; d) ventrite 1 flattened or slightly convex on disc. Otherwise female similar to the male.

Etymology. The new species is named after its type locality, Davao City.

Distribution. Metapocyrtus (Orthocyrtus) davaoensis sp. nov. is known from Calinan, Davao City and Gumitan, Davo del Sur, and Cabanglasan, Bukidnon. 


\section{Metapocyrtus (Orthocyrtus) hirakui sp. nov.} http://zoobank.org/B6BFAE9D-74BD-46B5-B6FF-C66AAE39BFFD Figs 5, 6

Holotype (Fig. 1A, B), male: Philippines - Mindanao / Bukidnon / Lantapan / July 2018 / coll. Medina (typed on white card) // HOLOTYPE male / Metapocyrtus (Orthocyrtus) hirakui / CABRAS, MEDINA \& BOLLINO, 2021 (typed on red card) Presently in UMCRC, it will be deposited in Philippine National Museum of Natural History (PNMNH) under the National Museum of the Philippines (NMP).

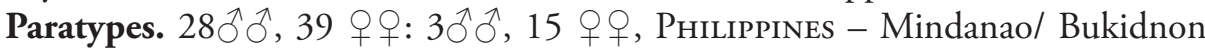

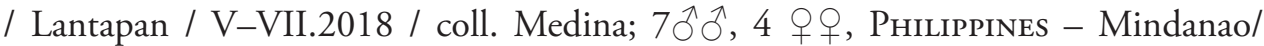

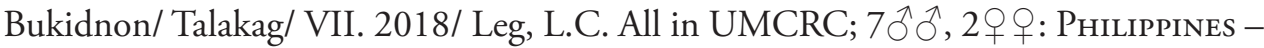
Mindanao / Cabanglasan - Bukidnon / III-IV.2013 / m. 800-1000 - Leg. Loc. people / coll. M. Bollino; 7ふ̋̂, 14우: Philippines - Mindanao / Cabanglasan (Bukidnon) / September 2013 / ex. N. Mohagan / Lg. local people - coll. Bollino; 1ð̄, 1q: Philippines - Mindanao / Cabanglasan / (Bukidnon) / December 2018 - January 2019 / Lgt. local people - coll. Bollino; 1ð̃: Philippines - Mindanao / Kalatungan / (Bukidnon) / X.2015 / ex I.Lumawig - coll. Bollino; $2 \widehat{\jmath}, 3$ 우 : Philippines - Mindanao / San Fernando - Bukidnon / X.2013 / ex Lumawig / lg. Local people - coll. Bollino, all in MBLI. All paratypes with additional red label: PARATYPE / Metapocyrtus (Orthocyrtus) hirakui / CABRAS, MEDINA \& BOLLINO, 2021

Diagnosis. Metapocyrtus (Orthocyrtus) hirakui sp. nov. differs from all other species of the subgenus for its unique elytral ornamentation consisting of yellow ochre to blue longitudinal stripes and striae I to II occasionally interrupted in the middle, although generally such striae are continuous from the base to the apex of elytra.

Description. Male. Dimensions (in mm): LB 10.6-10.9 (holotype 10.9, â: 10.75 ). LR: 1.9-2.0 (holotype 2.0, â: 1.95), WR 1.3-1.5 (holotype 1.5, â: 1.4), LP: 3.0-3.1 (holotype 3.0, â: 3.05), WP 3.0-3.1 (holotype 3.0, â: 3.05), LE: 6.9-7.0 (holotype 6.9, â: 6.95), WE: 4.9-5.0 (holotype 5.0, â: 4.95). $N=4$.

Integument black. Body surface, rostrum, head, and underside subopaque.

Body subglabrous. Head subglabrous, sparsely, minutely pubescent, with lightyellow ochre, round scales interspersed with metallic-white, hair-like, elliptical scales on lateroventral parts; forehead between eyes partially covered with metallic, lightyellow ochre, round scales; median groove barely distinct, not reaching the vertex. Rostrum sparsely, minutely pubescent, slightly longer than wide (LR/WR: 1.33), dorsum faintly, minutely punctured, bearing minute, yellowish hairs, white, recumbent, hairlike scales on the lateral surface, and long, light-brown hairs at the anterolateral margin; transverse basal groove distinct; basal half with shallow depression covered with metallic yellow ochre, round and elliptical scales; lateroventral part behind antennal scrobe densely covered with round to elliptical, white and yellow ochre scales, sparsely interspersed with short, hair-like white scales; dorsal surface weakly convex. Eyes medium-sized and feebly convex. Antenna moderately clavate, scape slightly shorter than funicle, moderately covered with fine, light-colored hairs. Funicular segments I and II almost of the same length, nearly three times longer than wide; 


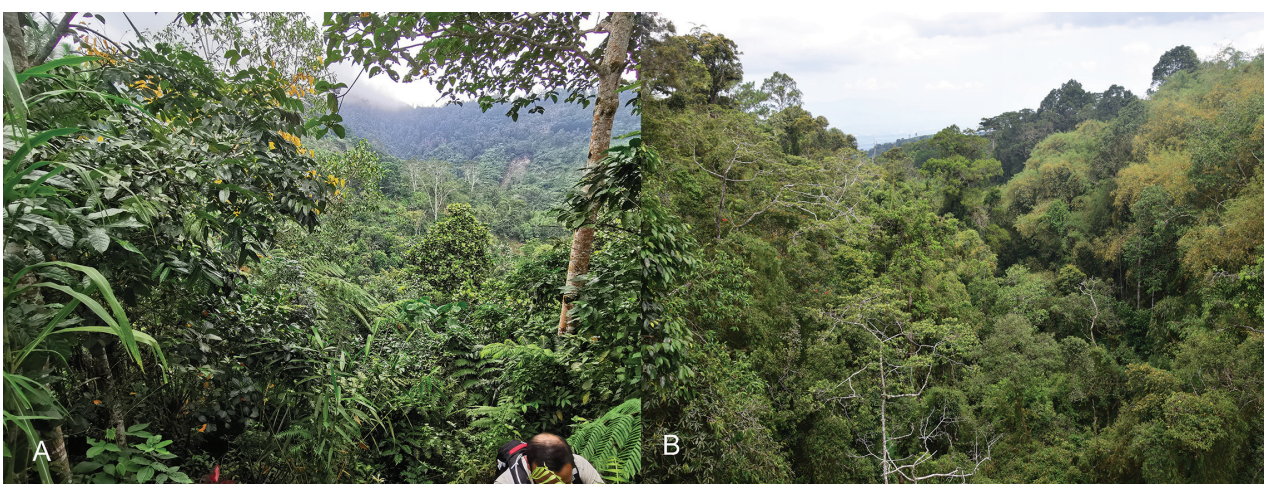

Figure 5. Habitat of Orthocyrtus spp. A O. davaoensis sp. nov in Davao City B O. hirakui sp. nov. in Lantapan, Bukidnon.

segments III-VII slightly longer than wide; club subovoid, nearly three times longer than wide. Prothorax subglobular, as long as wide (LP/WP 1.0), faintly punctured with sparse minute hairs, widest at middle, weakly convex, with a faint groove along midline reaching the middle, and with the following scaly markings of metallic light yellow ochre, and shagreen, round scales: a) thin band at the anterior margin, b) transverse band in the entire width in middle, and c) lateroventral stripe before the coxa confluent with the anterior margin and transverse band at middle. Elytra short ovate (LE/WE 1.38), wider and longer than prothorax (WE/WP 1.67, LE/LP 2.3), black, subglabrous, strongly convex with very minute and sparse setiferous punctures, each puncture with light-colored, short seta. Elytra with scaly bands of metallic light-yellow ochre, turquoise, and blue, round scales covering stria I-IX, beginning shortly from anterior margin and extending towards apex, sometimes stria I and II interrupted at middle creating a subcircular, broad, glossy black spot without scales. Stria I-IX confluent at anterior margin; stria I, II, III, VIII, and IX confluent at the apex. Stria IV and V confluent at apical quarter. Apex with light-colored hair. Legs with moderately clavate femora. Femora covered with light-colored hair and sparse, pale-blue elliptical, hair-like scales towards apical part. Tibiae covered with subrecumbent, light-colored bristles, and weakly serrate along inner edge. Fore and mid tibiae bear a mucro at apex, and hind tibiae with apical mucrones vestigial. Tarsomeres covered with sparse pubescence. Procoxae with light-colored hair covered with pale green and light yellow-ochre round to elliptic scales on the anterior side interspersed with white hair-like scales. Mesocoxae and metacoxae with light-green hairs and sparsely covered on the anterior side with pale-blue, hairlike, round scales, less dense on metacoxae. Mesosternum covered with light-colored, adpressed bristles. Metasternum with light-colored, adpressed bristles and sparse, light-yellow ochre, round scales at lateral sides. Ventrite 1 depressed on disc with light-colored, adpressed bristles and sparse, light-yellow ochre, round scales towards lateral margin interspersed with white, hair-like scales. Ventrite 2 with long, light-brown, adpressed bristles, shorter towards margin. Ventrites 3-5 with sparse, light-colored, short bristles. Ventrite 5 flattened, apical half finely densely punctured. 


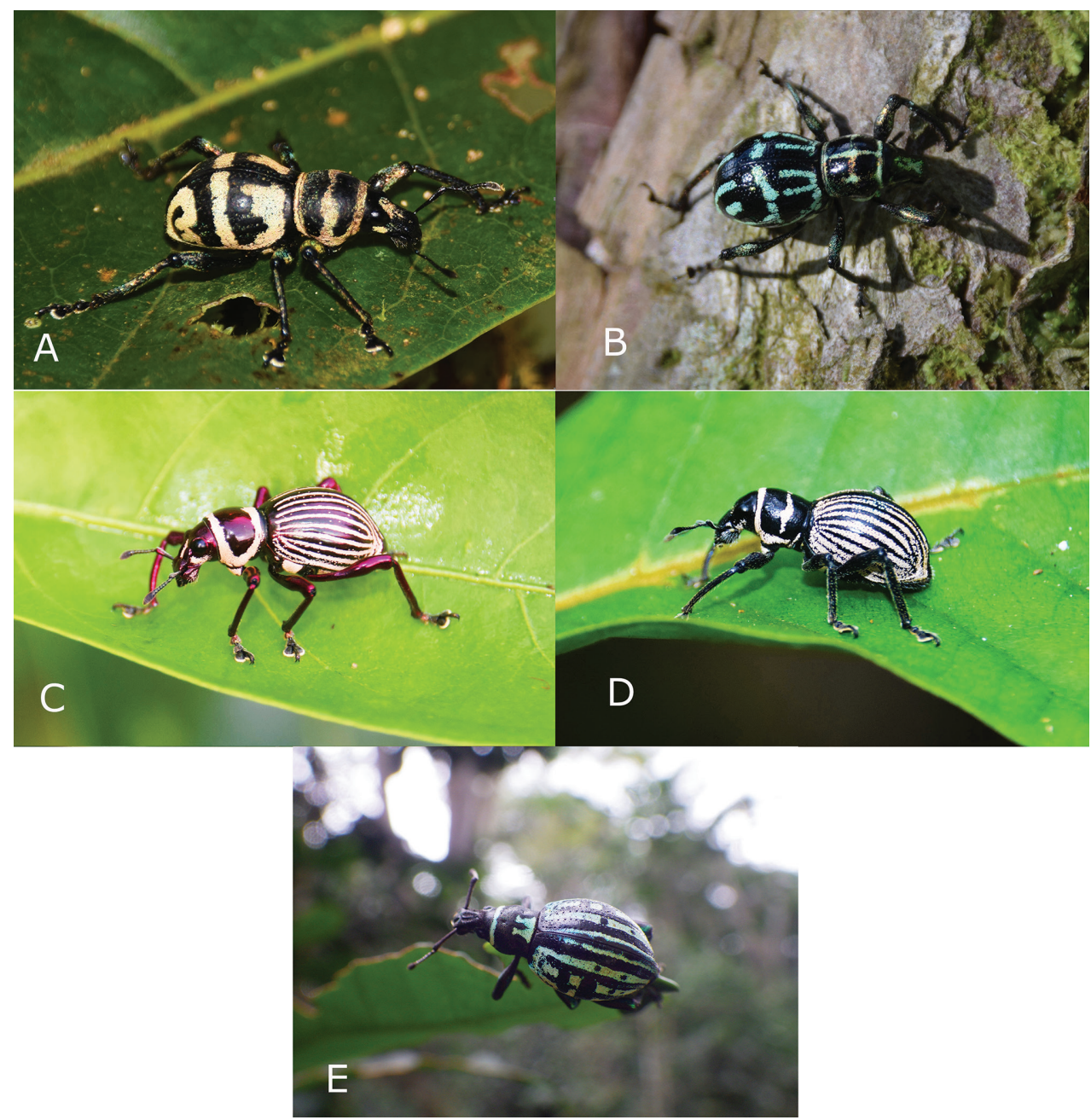

Figures 6. Mimicry of Metapocyrtus (Orthocyrtus) davaoensis sp. nov. and Metapocyrtus (Orthocyrtus) hirakui sp. nov. A $M$. (O.) davaoensis sp. nov. B Metapocyrtus kitangladensis C Pachyrhynchus tikoi D $M$. (O.) hirakui sp.nov. E Polycatus mimicus.

Male genitalia as shown in Figure 2A-C.

Endophallus as shown in Figure 3. Cabras, Bollino and Medina (2018) noted that obtaining the complete eversion of the endophallus in the subgenus Orthocyrtus is particularly complicated due to the long flagellar diverticulum, and attempts are very often subject to partial failure because the flagellar diverticulum itself tends to remain invaginated. Long series of males are needed to obtain a complete or even a partial but acceptable evertion, as it was in this case (18 males available, no full, nine partial, but only five acceptable partial evertions obtained).

Even if the number of completely everted endophalluses belonging to taxa of the subgenus Orthocyrtus is still very few, it is possible to try to hypothesize the taxonomic 
value of this genitalic structure. From what we have observed, the flagellar diverticulum does not seem to have a species-specific morphology and is quite uniform both in shape and in length, in contrast, for example, to the subgenus Artapocyrtus (Bollino, Sandel \& Yoshitake, 2019). What appears to have significant taxonomic value is the shape and presence/absence of the basal, baso-lateral, and median diverticula. In studying Orthocyrtus, the rate of acceptable eversion of the endophallus is about $30 \%$ of the samples tested, and although it is possible to obtain a complete evertion in approximately $1 \%$ of the samples, it will still take a long time before we can reach conclusions that are not just working hypotheses.

Female. Dimensions (in mm): LB 12.0-13.8 (â: 12.66), LR 2.0-2.2 (â: 2.12), WR 1.4-2.0 (â: 1.57), LP 3.2-3.8 (â: 3.56), WP 3.2-3.8 (â: 3.51), LE 8.9-10.0 (â: 9.14), WE 5.5-6.8 (â: 5.86). $N=15$.

Habitus as shown in Figure 1D-F.

Females differ from males by the following: a) head and rostrum mostly glabrous with only a few, sparse, yellow ochre, round scales and blue, hair-like scales on lateral and latero-ventral sides, b) pronotum slightly longer than wide in female (LP/WP $1.0)$, c) pronotum subglobular; thin, transverse, median band interrupted at middle, d) elytra subovate (LE/WE 1.47-1.62), slightly longer and wider (WE/WP 1.72-1.79, LE/LP 2.63-2.78) than male; stria I and II interruption at middle creating a subcircular, broad, glossy black spot without scales; e) ventrite 1 flattened or slightly convex on disc. Otherwise, femail similar to the male.

Etymology. The specific epithet is named after Hiraku Yoshitake (Tsukuba, Japan) for his great contribution in the advancement of studies on Pachyrhynchini in the Philippines.

Distribution. Metapocyrtus (Orthocyrtus) hirakui sp. nov. is known so far only from the province of Bukidnon.

\section{Brief ecological notes}

Specimens of $M$. (O.) davaoensis sp.nov. were collected on leaves of Swietenia macrophylla King (Meliaceae) at the ridge near Tamugan river in Calinan (Western part of Davao City) with an estimated altitude of $800 \mathrm{~m}$ (Fig. 5A). The biotope is a mix of secondary and agroforest. Barangay Calinan is characterized by rugged terrain and adjacent to several mountain ecosystems such as Mt. Carmen and Mt. Tamayong, with considerably higher elevation compared to the downtown area of Davao City. The river near where the new species was collected is quite pristine as evidenced by the presence of Odonates inhabiting only pristine fluvial systems such as Eupheae amphicyana Ris, 1930 and Neurobasis anumariae Hämäläinen, 1989. This biotope also has lush vegetation with several plants such as Medinilla sp. (Melastomataceae), Ficus spp. (Moraceae), Cyathea sp. (Cyatheaceae), and Bambusa spp. (Poaceae), among others. Despite the conversion of surrounding areas to maize and banana farms, it is still rich with Pachyrhynchini weevils particularly members of the genus Metapocyrtus. Some of the Metapocyrtus species documented within a radius of 500 meters from the banks of the 
river are Metapocyrtus (Dolichocephalocyrtus) lineaticollis Schultze, 1925, M. (Dolichocephalocyrtus) bituberosus Heller, 1912, M. (Trachycyrtus) apoensis Schultze, 1925 and M. (Trachycyrtus) adspersus Waterhouse, 1843. Compared with the aforementioned Metapocyrtus species which are abundant in the area, the new species is quite rare with only a few individuals documented. No species of Pachyrhynchus were observed. Moreover, the discovery of this new species within the remaining green spaces of Davao City reiterates the importance of our urban green spaces as a remaining haven for different species of flora and fauna and calls for immediate conservation measures.

Metapocyrtus (Orthocyrtus) hirakui sp.nov., on the contrary, was abundant in a secondary forest with some old growth trees near Lantapan, with an elevation of approximately $1200 \mathrm{~m}$ (Fig 5B) The new species was present all over the area and collected on several plants, namely Bridelia sp. (Phyllanthaceae), Oleandra sp. (Oleandraceae), Clerodendrum sp. (Lamiaceae), Ageratum conyzoides (Asteraceae), Camellia sp. (Theaceae), Medinilla sp. (Melastomataceae) and Nephrolepis sp. (Nephrolepidaceae). However, they were more abundant along trails and open areas. As documented previously, the majority of the Pachyrhynchini including Metapocyrtus are often collected along trails and ridges which are either fully or partially exposed to the sun (Cabras et al. 2019). The interior of the forest does not usually give an outstanding result in terms of collecting Pachyrhynchini.

\section{Notes on mimicry}

Mimicry is well investigated in butterflies but far less understood in beetles which possess equally interesting mimetic patterns (Meyer 2006). The first record of mimicry among Pachyrhynchini was noted by Wallace (1889), who noticed sympatric species sharing the same integument colours and elytral patterns. This was also noted by Schultze (1923, 1925), who provided a list of 19 sympatric species of Pachyrhynchus, Metapocyrtus, and Doliops sharing the same coloration and patterns. He also reported 14 sympatric species of Metapocyrtus, exhibiting very similar elytral patterns, which were only separable after a closer inspection of diagnostic characters such as the rostrum (Schultze 1925). A study by Tseng et al. (2014) found that the diverse mimicry of Pachyrhynchini weevils are taking advantage of their coloration as aposematic signals in deterring predators, exploiting predators' visual system. Pachyrhynchini do not possess toxins as in butterflies, but they do have a very hard elytra, which deter predators and act as a secondary defense of an aposematic insect (Schultze 1923; Wang et al. 2018). As mentioned by de Jager and Anderson (2019), mimicry can be confirmed using three conditions, namely "(1) characterizing a model, (2) identifying a receiver with a percept of said model, and (3) demonstrating that the receiver exerts selection on the mimic". This sympatric and allopatric convergence of colors and patterns has been greatly observed among Pachyrhynchini and other Entiminae weevil groups such as Alcidodes, Polycatus, Eupyrgops, Neopyrgops, Coptorhynchus, and the longhorned beetle Doliops, which can be an outstanding example of the mimetic complex. This occurrence has also been observed among spiders, and other insects of the orders 
Heteroptera and Orthoptera, which show superficial resemblance and body coloration and pattern (Wallace 1889; Cabras et al. unpublished).

Metapocyrtus (Orthocyrtus) davaoensis sp. nov. was collected at nearly the same locality as M. kitangladensis Cabras, Medina \& Zhang, 2019. This suggests a possible mimicry between these two species, for they have similar elytral markings. Photographic documentation suggests the presence of $M$. (O.) davaoensis sp. nov. in Marilog District, Davao City, where M. kitangladensis Cabras, Medina \& Zhang, 2019 was also documented. The importance of the geographic distribution of the model as the limiting factor for the effectiveness of the mimicry complex has already been established. As Ries and Mullen (2008) mentioned "the advantage of mimicry does not extend beyond the range of the model", although allopatric convergence of colors has also been documented.

Metapocyrtus (Orthocyrtus) hirakui sp. nov. belongs to a mimetic complex involving Pachyrhynchus tikoi Rukmane, 2016, Doliops valainisi Barsevskis, 2013, and Polycatus mimicus Bramanti, Bramanti, \& Rukmane, 2020, with all species sharing a superficial resemblance. These four species were collected in an area of less than 500 $\mathrm{m}$ diameter and at times from the same plant. Metapocyrtus (O.) hirakui and P. tikoi were very abundant in the secondary forest of Lantapan, Bukidnon, and could be easily interchanged due to their uncanny resemblance. Some Polycatus species have previously been recorded to possibly be part of the Pachyrhynchini mimicry complex. Sometimes they exhibit a perfect mimicry, looking exactly like some Pachyrhynchini models, while at other times they exhibit imperfect mimicry and do not have exactly the same pattern. According to Forsman and Appelqvist (1998), even only the superficial resemblance and coloration of the elytra of imperfect mimicry is enough to fool visual predators which mostly rely on patterns and coloration in their choice of prey. Polycatus can be easily distinguished from Pachyrhynchini by the rostrum which is entirely continuous with the head, the complete metepisternal suture, the distinct squamose scutellum, the definite epistome on the rostrum, and the antenna club which has the first joint much longer than the rest, together with its basal half narrowed into a conspicuous peduncle. As expected in this case of Batesian mimicry, mimics (Polycatus mimicus and Doliops valainisi) were much less numerous in the field than models (Metapocyrtus (Orthocyrtus) hirakui sp. nov. and Pachyrhynchus tikoi Rukmane 2016).

\section{Acknowledgements}

We express our gratitude to the National Geographic Society (GR-000000031) for the funding in the Jewel Weevil Mimicry Complex in Mindanao Island project, and CHED DARETO for funding the Coleoptera expeditions of AC and MNM to Davao City and other neighboring places through the Urban Biodiversity Research and Conservation project. We thank Dr Guillermo P. Torres for his continuous support to our coleopterological research; Chrestine Torrejos and Mark John Pepito, both members of 
the research team of the Coleoptera Research Center; Efrain Loidge Pajota for helping in the images; Dr Arvids Barševskis for the continuous support, especially during our visit to Ilgas; Dr Hiraku Yoshitake during the first author's visit to Institute for AgroEnvironmental Sciences, NARO, Tsukuba, Japan (NIAES); Dr Klaus-Dieter Klass and Olaf Jäger for their help during our visits to Senckenberg Natural History Collections, Dresden, Germany. A special thanks is due also to Jordan Lim for the English review and the anonymous reviewers for helping improve the manuscript.

\section{References}

Bollino M, Sandel F (2017) Two new taxa of the subgenus Artapocyrtus Heller, 1912, genus Metapocyrtus Heller, 1912 from the Philippines (Coleoptera, Curculionidae, Entiminae, Pachyrhynchini). Baltic Journal of Coleopterology 17(1): 1-14.

Bollino M, Sandel F, Yoshitake H (2019) Four new species of the genus Metapocyrtus Heller, subgenus Artapocyrtus Heller (Coleoptera, Curculionidae, Entiminae) from the Philippines. Elytra New Series 9(2): 395-340.

Bollino A, Medina MN, Cabras A (2020) Three new Metapocyrtus Heller, 1912 (Curculionidae, Entiminae, Pachyrhynchini) from Mindanao Island, Philippines. Journal of Tropical Coleopterology 1(1): 26-38.

Bontems C (2013) Le procédé Berti-Vachon d'évagination du sac interne. Nouvelle Revue d'Entomologie (Nouvelle Série) 29(1-2): 85-91.

Brown RM, Diesmos AC (2001) Application of lineage-based species concepts to oceanic island frog populations: the effects of differing taxonomic philosophies on the estimation of Philippine biodiversity. Silliman Journal 42: 133-162.

Cabras A, Bollino M, Medina MN (2018) A new species of the subgenus Orthocyrtus, genus Metapocyrtus (Coleoptera, Curculionidae, Entiminae, Pachyrhynchini) from Mindanao, with notes on its ecology. Baltic Journal of Coleopterology 18(1): 39-46.

Cabras A, Medina MN, Zhang G (2019) Metapocyrtus kitangladensis sp. n., a new Pachyrhynchus cumingii GR Waterhouse, 1841 mimic from Mindanao Island, Philippines. ZooKeys 853: 119-129. https://doi.org/10.3897/zookeys.853.30595

Cabras A, Medina MN (2019) Metapocyrtus ginalopezae sp. n., a new Orthocyrtus from Davao de Oro, Mindanao Island. Baltic Journal Coleopterology 19(2): 205-211.

DENR Administrative Order (2019) Department of Environment and Natural Resources Administrative Order No. 2019-09. Updated National List of Threatened Philippine Fauna and their Categories. https://bmb.gov.ph/index.php/e-library/laws-and-policies/denradministrative-orders/dao-2017-2020?download=383:denr-administrative-order-2019-09 [Accessed on 2021-3-17]

de Jager M, Anderson B (2019) When is resemblance mimicry? Functional Ecology 33: 15861596. https://doi.org/10.1111/1365-2435.13346

Forsman A, Appelsqvist S (1998) Visual predators impose correlational selection on prey color pattern and behavior. Behavioral Ecology 9(4): 409-413. https://doi.org/10.1093/beheco/9.4.409 
Meyer A (2006) Repeating patterns of mimicry. PLoS Biology 4(10): e341. https://doi. org/10.1371/journal.pbio.0040341

Ries L, Mullen SP (2008) A rare model limits the distribution of its more common mimic: a twist on frequency-dependent Batesian mimicry. Evolution 62(7): 1798-1803. https:// doi.org/10.1111/j.1558-5646.2008.00401.x

Rohling EJ, Fenton M, Jorissen FJ, Bertrand G, Ganssen G, Caulet JP (1998) Magnitude of sea level lowstands of the last 500,000 years. Nature 394: 162-165. https://doi. org/10.1038/28134

Schultze W (1923) A monograph of the pachyrrhynchid group of the Brachyderinae, Curculionidae: part I. The genus Pachyrrhynchus Germar. Philippine Journal of Science 23(6): 609-673. [6 pls]

Schultze W (1925) A monograph of the pachyrrhynchid group of the Brachyderinae, Curculionidae: part III. The genera Apocyrtidius Heller and Metapocyrtus Heller. Philippine Journal of Science 26(10): 131-310. [12 pls]

Tseng HY, Lin CP, Hsu JY, Pike DA, Huang WS (2014) The functional significance of aposematic signals: geographic variation in the responses of widespread lizard predators to colourful invertebrate prey. PLoS ONE 9(3): e91777. https://doi.org/10.1371/journal. pone.0091777

Wallace AR (1889) Darwinism: an exposition of the tTheory of Natural Selection, with some of its applications. Macmillan and Company, New York, 528 pp. https://doi.org/10.5962/ bhl.title.17416

Wang LY, Huang WS, Tang HC, Huang LC, Lin CP (2018) Too hard to swallow: a secret secondary defence of an aposematic insect. Journal of Experimental Biology 221: jeb172486. https://doi.org/10.1242/jeb.172486

Yumul GP, Dimalanta CB, Tamayo RA, Maury RC (2003) Collision, subduction and accretion events in the Philippines: a synthesis. Island Arc 12: 77-91. https://doi.org/10.1046/ j.1440-1738.2003.00382.x 